\title{
„W mŁodości byŁem Tezeuszem”. Perspektywa senilna W TWÓRCZośCI JaCKa KaCZMARSKIEgo
}

Zbiór, na który składają się pieśni Jacka Kaczmarskiego, można określić przede wszystkim jako politematyczny. Pojawiają się w nim wątki najróżniejsze, co przypomina o szerokim horyzoncie zainteresowań autora słynnej Zbroi. Liryczne bogactwo dotyczy zarówno tematów, relacji intertekstualnych, głębokiego osadzenia w kulturze, jak i formy poetyckiej, precyzyjnej dbałości o słowo, które w artystycznym projekcie piosenki literackiej, jaką zaproponował Kaczmarski, odgrywa rolę zdecydowanie pierwszoplanową. Dlatego też Krzysztofowi Gajdzie, pierwszemu monografiście tej twórczości, zależało na odparciu ewentualnych zarzutów o literaturoznawczą lekturę samych tekstów piosenkowych, a więc oderwanych od warstwy muzycznej oraz wokalno-instrumentalnej. Badacz tłumaczy swą optykę między innymi tak:

Jacek Kaczmarski z wielką swobodą porusza się po świecie literatury i sztuki. Jego piosenki świadczą o autentycznej erudycji, która pozwala uruchamiać rozmaite konteksty kulturowe i uzyskiwać zaskakujące czasem efekty poetyckie. [...] Język poetycki autora Kanapki z człowiekiem jest bogaty w porównaniu z innymi dokonaniami gatunkowymi i nierzadko daje podstawy do analizy tekstu w oderwaniu od muzyki ${ }^{1}$.

Także rozważanie poszczególnych tematów rozwijanych w całej twórczości Kaczmarskiego wydatnie pokazuje spójność poetycką tego tekstowego uniwersum. Nierzadko więc powracają pewne wątki, ukazują się tu i ówdzie wyraziste miejsca wspólne. Trudno w tym momencie wskazać kompletny katalog takiego świata pieśni², jednak nadrzędną cechą uwidaczniającą się w poetyckiej propozycji autora Źródta okazuje się wieloaspektowość. Ten sam temat jest nierzadko oświetlany z odmiennych per-

\footnotetext{
* Kamil Dźwinel - (rocznik 1988) doktorant w Instytucie Literatury Polskiej Uniwersytetu Mikołaja Kopernika w Toruniu, laureat Nagrody „Archiwum Emigracji” za pracę magisterską. Zajmuje się problematyką twórczości bardowskiej oraz związkami literatury i muzyki. Przygotowuje rozprawę poświęconą poetyce oraz nurtom pieśni literackiej, skupiając swoje badania nad lirycznym prymatem tekstu pieśniowego. Interesuje się ponadto kulturą czeską oraz współczesną poezją i dramatem polskim. Publikował między innymi w „Przeglądzie Humanistycznym”, „Tekstualiach” oraz „Ruchu Literackim”.

${ }^{1}$ K. Gajda, Jacek Kaczmarski w świecie tekstów, nowe wydanie, popr. i poszerz., Poznań 2013, s. 21.

${ }^{2}$ Jeden z badaczy podjął tego typu próbę, jednak liczba uproszczeń, aberracji i niejasności interpretacyjnych prowadzonego przezeń wywodu podważa zasadność traktowania jego rozważań jako dobrego punktu wyjścia, zob. P. Wiroński, Wbrew, pomimo i dlatego. Analiza twórczości Jacka Kaczmarskiego, Kraków 2011.
} 
spektyw, co wiąże się natomiast z często występującą w tych tekstach liryką roli, czyli — najprościej rzecz ujmując — wcielaniem się zarówno w zwykłe, bezimienne postaci (emeryta, podróżnego, dziecka i tak dalej), jak i jednostki wybitne, które znalazły swe miejsce w historii lub kulturze (Andrieja Rublowa, Władimira Wysockiego, Stańczyka i wielu innych). Na potrzeby obecnego studium za punkt wyjścia wystarczy przyjąć dwie nadrzędne cechy pieśni Kaczmarskiego: jej tekstualny wymiar — prymat semantyki poetyckiej i lirycznych środków wyrazu — oraz bogactwo, wobec którego stajemy, zagłębiając się w skonstruowany przez barda, niezwykle złożony świat. Uwidacznia się w nim zresztą wielość perspektyw nadawczych i myślowych sprzyjająca poszukiwaniu prawdy artystycznej, ale przede wszystkim tej egzystencjalnej, jednostkowej. Prawdy o człowieku i jego świecie, w swej różnopostaciowości czerpiącej z doznań uniwersalnych, czasem skrytych pod maską zniechęconego Stańczyka, a czasem — przerażonego przedszkolaka.

Główny przedmiot badawczego zainteresowania stanowi tu wątek starości w twórczości Jacka Kaczmarskiego obecny od jej początków (Starzy ludzie w autobusie z debiutanckiego programu Mury) aż do końca (pomieszczone w tomie Tunel wiersze Starość Tezeusza czy Stary poeta drzemie). Zostaną więc omówione te utwory, w których perspektywa komunikacyjna aktualizuje się w podmiocie doświadczonym starością (pierwszoosobowym, jak w Starości Tezeusza, lub zbiorowym, jak w Starych ludziach w autobusie lub Portrecie zbiorowym we wnętrzu - Dom Opieki). Co znamienne, niezwykle często jest to podmiot-artysta (Ostatnie dni Norwida, Starość Owidiusza czy Stary Michat Aniot i Pieta Rondanini) — z uwagi na to wiersze tego typu zostaną omówione najszerzej. Wreszcie ostatnim wyraźnym podzbiorem w nurcie utworów na temat sędziwego wieku są te teksty, w których świat starego człowieka stanowi przedmiot refleksji (np. Dęby).

Pośród wierszy dotyczących starości wyróżnia się w dorobku Kaczmarskiego grupa tekstów, w których mowa o schyłku życia rozmaitych artystów. W cyklu Kosmopolak sąsiadują z sobą trzy utwory z tym związane: Ostatnie dni Norwida, Starość Owidiusza oraz Witkacy do kraju wraca ${ }^{4}$. W pierwszym z nich nadawca liryczny jest kreowany

\footnotetext{
${ }^{3}$ Sam Kaczmarski unikał określania m.in. Kosmopolaka mianem programu, czyli spójnego, lecz wieloperspektywicznego cyklu tematycznego, którego bodaj najwyraźniejszymi reprezentacjami są Raj, Muzeum, Sarmatia czy Wojna postu z karnawatem. Zob. K. Nowak, Od redaktora wydań zbiorowych poezji Jacka Kaczmarskiego, [w:] J. Kaczmarski, Antologia poezji, Warszawa 2012, s. 26-27.

${ }^{4} \mathrm{~W}$ ten mikrocykl wpisuje się również utwór Ambasadorowie, odróżniający się jedynie perspektywą: mamy w nim do czynienia już nie z pierwszoosobową narracją, a z opisem, i to ekfrastycznym, odwołującym się do obrazu Hansa Holbeina młodszego. Jako ciekawy kontrapunkt prezentuje się — w kontekście podejmowanych w przedłożonym szkicu rozważań — komentarz interpretacyjny do tego płótna: „cała promieniująca z obrazu moc i potęga okazuje się być nie tryumfem Cyfry i Litery, a chwilowym kaprysem Losu. Potężni francuscy dyplomaci okazali się bezbronni wobec przemijania, a współcześnie nie pamiętałby o nich nikt, oprócz specjalistów, gdyby nie to, że stali się tłem dla niepozornej, amorficznej czaszki” (I. Grabska, Jacek Kaczmarski — „Ambasadorowie”, [w:] I. Grabska, D. Wasilewska, Lekcja historii Jacka Kaczmarskiego. Obraz / wiersz / komentarz, Warszawa 2012, s. 29).
} 
na autora Promethidiona (notabene do tego właśnie tekstu odnosi się incipit Ostatnich $d n i)^{5}$, przedostatnia strofa przynosi zaś obraz samotnej starości Cypriana Norwida:

\footnotetext{
Ręce grabieją, wino całkiem kwaśne, Na rękawiczki braknie mi pieniędzy I myśl zmarznięta nie chce płynąć prędzej, A przecież przez nią i to dla niej właśnie Umieram w nędzy ${ }^{6}$.
}

Artysta nie miał do nikogo pretensji, wiedział, że jego starcza nędza to konsekwencja oddania poetyckiemu słowu. Kaczmarski pragnął podkreślić Norwidowską samoświadomość, pozwalając staremu, schorowanemu poecie na skonstatowanie własnej niemocy, słabości swojej kondycji. Pokazał go w chwili, kiedy zmęczone ciało synchronizowało się także ze spowolnieniem, zgrabieniem myśli jak rąk na mrozie ${ }^{7}$. Sugestia godzenia się z własną niemocą pod koniec życia pojawiła się również w Starości Owidiusza:

Stoją nade mną tubylcy pachnący czosnkiem i czuję,

Jak zmieniam się w list do Stolicy, który nikogo nie wzrusza.

Kiedyś tu będzie Rumunia, Morze — już Czarne — faluje

I glebą pieśni się staje ciało i świat Owidiusza.

(Starość Owidiusza, s. 283)

Stary Owidiusz wygnany na obce ziemie, odłączony od ukochanych kolumn swego Rzymu, próbował zrozumieć własną sytuację, pragnął znaleźć coś nieprzemijalnego — i okazało się, że bycie glebą pieśni, podłożem, początkiem, prawodawcą tradycji jest czymś trwalszym, wykraczającym poza materialność i okolicznościowość bycia. Tak jak stary Norwid rozumiał, że zostawił po sobie poetycką myśl, tak też zbliżający się do swego kresu Owidiusz widział, jak „Geometria pamięci przodków wyzbyta brzydoty" (Starość Owidiusza, s. 283) obejmowała również jego życie i dzieło. Pod piórem Kaczmarskiego to wyznanie ma charakter niezwykle prywatny, należy przeto pamiętać, że oba utwory powstały na emigracji, wyrastają więc z doświadczeń bliskich zarówno autorowi Fortepianu Szopena, jak i twórcy Tristiów. Starzy artyści, nie tylko wiekiem, ale i doświadczeniem — zatem dotyczy ta uwaga również Witkacego (Witkacy do kraju wraca) — rozważali w obliczu osłabienia ciała, uwiądu myśli czy po prostu śmierci (autor Narkotyków mówi przecież w wierszu Kaczmarskiego post mortem) nie

\footnotetext{
${ }^{5}$ Zob. szerzej M. Margiel, „Piękno jest na to żeby zachwycato” („Ostatnie dni Norwida” Jacka Kaczmarskiego), [w:] Od oświecenia ku romantyzmowi i dalej... Autorzy — dzieła — czytelnicy, cz. 2, red. M. Piechota, J. Ryba, Katowice 2007.

${ }^{6}$ J. Kaczmarski, Antologia poezji, Warszawa 2012, s. 281. Dalsze cytaty z wierszy Kaczmarskiego będą lokalizowane za tym wydaniem poprzez podanie tytułu wiersza i numeru strony.

7 Zob. kontekstowo artykuł Anity Jarzyny, O lekturze koniecznej. Starość Cypriana Kamila Norwida w późnej poezji wspótczesnej, [w:] Egzystencjalne doświadczenie starości w literaturze, red. A. Gleń, I. Jokiel, M. Szladowski, Opole 2008, s. 141-152.
} 
tyle nawet wartość swego dorobku, ile w ogóle wartość sztuki, sens poświęcania się czemuś tak niepewnemu - trwałemu i ulotnemu zarazem. Zresztą już sam wybór intertekstualny, sam fakt sięgnięcia po biografie twórcze innych artystów świadczy o uniwersalności praw rządzących światem. Gdy Kaczmarski poszukiwał odpowiedzi na pytania nie tylko o sens sztuki, ale również o sens starości — sięgał w głąb kultury, w której odnajdywał podstawy własnej ich wykładni. „Z Ariadny powstaje pająk” (s. 282) — jest tak, jak w Starości Owidiusza, gdzie istota tworzenia to powracanie do źródeł i pierwocin. Pieśniowa hermeneutyka, jaką uprawiał autor Mimochodem, należy bez wątpienia do wyrafinowanych, epistemologiczno-poetyckich poszukiwań na miarę tych, prowadzonych przez Zbigniewa Herberta — poetę, który był dla Kaczmarskiego niezwykle ważny, inspirował go, a nawet stał się bohaterem kilku jego utworów ${ }^{8}$.

Już krzepnący w „list do Stolicy” Owidiusz czy wynędzniały na paryskim bruku Norwid — sygnalizowali, pod piórem Kaczmarskiego, swe wątpliwości wobec statusu sztuki i jej niezłomnego uprawiania. Kolejny bohater wiersza o schyłku życia artysty — Michał Anioł, będący zarazem podmiotem lirycznym (jak widać w podanych przykładach, to częsta strategia nadawcza stosowana przez barda) — również nie szczędził słów swoistej autokrytyki:

\author{
Nie dźwigniesz Matko swego Syna \\ Ja nie oddzielę Go od skały \\ Już nie mam zresztą dłut \\ (Stary Michat Aniot i Pieta Rondanini, s. 752)
}

W kontekście przywołanego wiersza Olga Kaczmarek zauważyła: „prawdopodobnie niedokończona rzeźba starego mistrza odczytana zostaje jako porażka, dowód kapitulacji i niemocy twórczej", dalej natomiast zrekonstruowała badaczka wyłożoną w tym wierszu koncepcję twórczości, zasadzającą się na rozumieniu sztuki jako nośnika artykulacji niewyrażalnego, jako narzędzia, które umożliwia głębinowe poszukiwanie sensu i jego (nawet tak szczątkowej, jak niewykuta do końca pieta) reprezentacji, w tym wypadku poetyckiej (choć konteksty syntezy sztuk, ekfrastyczności, transpozycji nie pozostają tutaj bez znaczenia). Starość artysty może więc stanowić ten okres, w którym wypowiada on swoje właściwe credo. W wypadku Michała Anioła okazało się ono o tyle wyjątkowe, że sprowadziło się do w-rzeźbionego, włożonego w usta Chrystusa rozpaczliwego pytania: „Po co? Po co? / Po co lepiłem lalki skoro / W ziemię

\footnotetext{
${ }^{8} \mathrm{Na}$ wirtualny cykl herbertowski składają się trzy wiersze Kaczmarskiego: Zbigniewowi Herbertowi, Kwestia odwagi oraz Tren spadkobierców. Ważny kontekst stanowią także teksty autora Pana Cogito wykonywane przez trio Kaczmarski, Gintrowski, Łapiński w programie Raj: Sprawozdanie z raju, Przestuchanie anioła i $U$ wrót doliny, są bowiem wyborem znaczącym, szczególnie, że dotyczą Herbertowskiego rozumienia zaświatów. Wątek ten należy bez wątpienia zdecydowanie włączyć do ewentualnej refleksji nad Herbertem Kaczmarskiego.

${ }^{9}$ O. Kaczmarek, Sens życia w prostym symbolu? Koncepcja sztuki w wybranych ekfrazach Jacka Kaczmarskiego, [w:] Zanurzeni w historii - zanurzeni w kulturze. Jacek Kaczmarski, red. M. Karwala, B. Serwatka, Kraków 2009, s. 100 i n.
} 
zamieniam się?" (Stary Michat Aniot i Pieta Rondanini, s. 752). Kaczmarski pokazuje więc już w swoich wczesnych dokonaniach (wiersz o genialnym rzeźbiarzu pochodzi z 1979 roku), że w obliczu śmierci nie ma łatwych odpowiedzi, zostają natomiast nierozstrzygalniki, wątpliwości, wyrzuty sumienia, niepewność i przytłaczające jak ciężar Chrystusowej piety pytanie, czy raczej wołanie o sens — wołanie, którego młodość chyba jeszcze często nie zna.

Po raz kolejny powrócił Kaczmarski do perspektywy podmiotu-artysty w Sądzie nad Goya, w którym:

Głuchy zdycha mało godnie:

Stęka, skarży się i gdera,

Cuchnie jakby robił w spodnie;

Balwierz żyłę mu otwiera.

[...]

Ze starości Głuchy zdycha,

Osiemdziesiąt lat żył Głuchy.

(Sąd nad Goya, s. 652)

— niemoc Francisca Goi podkreślana jest nieustannie. Głuchota, która w połowie życia zamknęła jego wizyjny, mroczny umysł na świat dźwięków, została wyniesiona do rangi „pasa ochronnego":

Szatan się ze śmiechu trzęsie,

Zapluwają się staruchy;

Goya myśli — miałem szczęście,

Żem i żył i umarł — głuchy.

( Sąd nad Goya, s. 653)

Autor Mai nagiej niejednokrotnie malował postaci zgarbionych, starych ludzi, odpychających swą fizycznością, natomiast w ujęciu Kaczmarskiego sam przynależał do tego świata: naturalistycznego, dotkliwego, odpychającego, ułomnego — ludzkiego. Goya zafascynowany makabrą i obrzydliwością okazał się artystą wzniosłym, zbliżającym się w swoim asocjacyjnym, groteskowym panoptikum osobliwości i codzienności, jaki stanowi jego malarstwo, do tajemnic ukrytych w doczesnym świecie. Wykraczał zresztą dalej, ku „Bogu-sadyście” (Sąd nad Goyą, s. 652) i ku trzęsącemu się ze śmiechu Szatanowi (tamże, s. 653).

Jednak nie tylko mroczne wizje starości można znaleźć w pieśniach Kaczmarskiego. Zdarzają się bowiem i takie, w których po dobrze przeżytym żywocie (a znaczy to: żywocie refleksyjnym, spędzonym jednocześnie w ciagłym, niejako młodzieńczym otwarciu na świat) następował schyłek niebędący ciężarem — jak w Janie Kochanowskim:

Kto i bawić się umiał i nie bał się myśleć,

Temu starość niestraszna pod lipowym liściem.

Miło dumać wśród brzęku pszczół nad bytowaniem -

Czy się zboża wykłoszą, a czy kuśka stanie! 
Czy w powszechnej niezgodzie kraj się znów pogrąży,

Czy się księgę ostatnią w druku ujrzeć zdąży,

Która gwiazda na niebie moja - ta co spada,

Czy ta nad widnokręgiem, co jutrzenką włada?

Tylu bliskich i dalekich dzień po dniu odchodzi

A ja żyję w lat bogactwie, co mi schyłek słodzi...

(Jan Kochanowski, s. 491)

Niezależnie od tego czy starość artysty to czas utyskiwań i lęków, czy afirmacji i radości - pozostaje ten etap życia czasem wspomnień i rozliczeń z przeszłością. Kochanowski - po raz kolejny użył Kaczmarski nadawczej kliszy wcielenia się w daną postać (kontaminując ironicznie lirykę maski i roli) — wspomniał bogactwo minionych lat, wpisując się jednak w perspektywę nienasycenia („rozkoszy nienasyceń”) urokami życia, oddalił przy tym jego mroki. Wyznał przecież: „Im mniej cię co dzień, miodzie — / Tym mi smakujesz słodziej" (Jan Kochanowski, s. 491). Autorowi Naszej klasy udało się w Janie Kochanowskim uzyskać efekt kolistości. W kolejnych strofach poznajemy tego ojca poetów, jego ciekawą biografię, sposób myślenia o świecie, by na końcu uzyskać coś w rodzaju programu pozytywnego, zachwycenia życiem, euforii bytowania, które summa summarum okazało się podróżą przez piękno i dobro. Pochodzący z tego samego okresu utwór Zbigniewowi Herbertowi (oba teksty włączył bard jako epilogi do programu Wojna postu z karnawatem) otwiera fraza:

Oto oswajam śmierć — szlifuję soczewkę pamięci

(Zbigniewowi Herbertowi, s. 492).

Perspektywa życia jako oswajania śmierci okazała się obu poetom wspólna, pomimo wszelkich różnic wpisanych w te dwa wielkie, ważne projekty liryczne. Niejako pomiędzy Kochanowskim a Herbertem pomieściło się nieprzebrane bogactwo życia, które w obliczu śmierci pozwalało „ubytawiać” niebyt, przy łożu śmierci pozostawić otwartą księgę wierszy. Wiekowy artysta zostawił po sobie tylko tyle i aż tyle. Bywa i tak, jak w późnym wierszu Kaczmarskiego Stary poeta drzemie:

Bo tylko Młodość wieszczy, bezwzględnie natchniona;

$\mathrm{z}$ wiekiem się uczłowiecza, człowieczejąc — kona.

Wszelka wiedza w opadłej powiece zamknięta;

Ten o oczach zamkniętych już wie, bo pamięta.

I ten tylko, co oczy na chwilę otworzy -

$\mathrm{z}$ tej pamięci niekiedy coś, być może, stworzy...

(Stary poeta drzemie, s. 1115)

Schyłek życia artysty nie oznaczał schyłku twórczej aktywności. Choć przesunęła się ona w odmienne rejestry, to nie była już tak skora do natchnionych wieszczeń 
i zbliżyła się raczej ku ściszonym przepowiedniom ${ }^{10}$. I tym razem pokazał Kaczmarski procesualność ludzkiego istnienia, w przypadku artysty zwielokrotnioną chwilami twórczych przebudzeń.

Prócz perspektywy wiążącej się ze starością artysty można odnaleźć w dorobku autora Obławy także utwory operujące poetyką podmiotu zbiorowego, dzięki któremu senilny głos zyskuje na wyrazistości. Starzy ludzie w autobusie to ironiczny manifest przeciw bezsilności. Tytułowi bohaterowie dali upust swoim emocjom towarzyszącym wykluczeniu przez wzgląd na swe starcze słabości. Co najważniejsze, mimo wyraźnej przewagi witalnej, jaką miał nad nimi „chór pasażerów” — potrafiący słabych starców jedynie „dobrotliwie" karcić (93) - śpiewają oni swoją pieśń bezsilności, pieśń rezygnacji. Okazała się ona uderzającym świadectwem, poetyckim reportażem o odrzuceniu, wyobcowaniu, przymusowej alienacji. Tajemniczy, omnipotentny kierowca autobusu oraz pasażerowie o obcych plecach, bez twarzy, autobus jako komunikacyjna klatka ciszy — sprawiali, że wiersz ten można traktować jako postróżewiczowskie echo Listu do ludożerców. Wyraźnie skonstatował tu Kaczmarski XX-wieczne zamknięcie na dialog:

\footnotetext{
Ze skargą do kierowcy znów

Aż ktoś nie przerwie narzekania

Napis wskazując nam bez słów

Że z Nim rozmawiać się zabrania!

Lub pasażerów chór nas zdławi

I dobrotliwie skarci nas

Dwie możliwości nam zostawi:

Pętlę — lub do zajezdni zjazd!

(Starzy ludzie w autobusie, s. 93)
}

Jeszcze wyraźniej zaś wyartykułował autor, wykorzystując polisemiczność wyrazów, tę tragiczną „,bezalternatywną alternatywę”, w której pozostały pętla (także: sznura) lub zajezdnia. Ironia tego wiersza zasadza się jednak na tym, że starzy ludzie wybrali drogę trzecią — próbę przełamania tej patowej sytuacji przez nazwanie swoich problemów, przez przedstawienie trudnej sytuacji zdławienia. Pokazane w utworze senilne ograniczenia — brak sił fizycznych, wiążąca się z tym ogólna słabość, powolność — umożliwiły Kaczmarskiemu skonstruowanie grupy słabych, po których stronie mamy szansę stanąć. Wysłuchanie tej historii ma otworzyć na problematykę znacznie szerszą, aniżeli tylko szacunek należny seniorom i pokazać, że tam, gdzie nie opowiadamy się po stronie słabszych, poniżonych, wykluczonych i zapomnianych, pozostało smutne piekło ludzkiego zobojętnienia, niepamięci, samotności czy bezsilności. Starość posłużyła tu więc za entourage, za ośrodek metafory życia w trudnych (politycznie, egzystencjalnie...) czasach, przypominając jednocześnie o swej własnej godności.

\footnotetext{
${ }^{10}$ Warto pamiętać w tym miejscu również o dwóch innych wierszach Kaczmarskiego: Błędy wróżbitów oraz Starzejesz się, stary.
} 
Analogicznie ujęty problem pojawił się w utworze Kaczmarskiego Portret zbiorowy we wnętrzu - Dom Opieki, będącym zarazem ekfrazą obrazu Fransa Halsa, gdzie „poeta oddał głos Halsowi jako przedstawicielowi podopiecznych domu"11:

Surowo na nas patrzą szafarki dni ostatnich
W milczeniu oskarżają, żeśmy się zestarzeli.
Zmieniają prześcieradła - wyrodne nasze matki
Nienawidzące dzieci w wykrochmalonej bieli
Jak one - pomarszczonych na tle poduszek gładkim.
(Portret zbiorowy we wnętrzu - Dom Opieki, s. 481)

Tutaj również pojawiły się — podane ironicznie — utyskiwania na starość. Opiekunki, „wyrodne matki”, z najsurowszą dyscypliną, a jednocześnie z ogromną niechęcią pilnowały grupy schorowanych starców. „Przynoszą nam posiłek, jak dar na zmarnowanie" - narzekali ci, jak sami siebie określali (przypomnijmy, w ujęciu Kaczmarskiego utyskiwali ustami Halsa), „pensjonariusze łaski”, de facto zniewoleni w groteskowym świecie Domu Opieki, gdzie są ciężarem dla innych, wyrażając jednocześnie niezbywalną, biologiczną wolę życia. Ponownie pojawiły się naturalistyczne obrazy powiązane ze starością, z których bodaj najwyrazistszym był ten, gdzie mowa o płynięciu „krypą pryczy po swym przedśmiertnym pocie” (Portret zbiorowy we wnętrzu - Dom Opieki, s. 481). Bohaterowie tego wiersza próbowali zracjonalizować zaistniałą sytuację w następujący sposób:

\footnotetext{
Kapłanki dyscypliny bez odstępstw, bez wyjątków

Pilnują nas bez przerwy żółtymi powiekami,

Byśmy — nieobliczalni, skąpani jak we wrzątku,

Znów — życiem nienażarci — nie stali się chłopcami

I świata nie zaczęli urządzać od początku.

(Portret zbiorowy we wnętrzu - Dom Opieki, s. 481)
}

To przytłoczenie niechęcią i obojętnością „kapłanek dyscypliny” miało na celu zniwelowanie ostatniego już być może z aktów buntu, jaki przyszło podjąć starcom, tym śmiesznym i wielkim jednocześnie, przedśmiertnym figurom. Buntu wobec przemijania. Pensjonariusze z omawianej ekfrazy wpisywali zarazem swój świat, szczególnie u jego kresu, w pragnienie, które zostało doskonale zaforyzowane w innej pieśni Kaczmarskiego, Nadzieja śmiełowska: „Że młodość w życiu się nie rozmyje” (s. 602). W utworach autora Mimochodem starość to ostatni człon długiej definicji ludzkiego życia, przygotowywanej w procesie samopoznawania, mieszczącej w sobie fizyczny strach umierania i metafizyczną nadzieję sensu. Nastąpiła więc późna przemiana niewinności w doświadczenie; w tym właśnie miejscu rozegrało się właściwe, konieczne napięcie starości i młodości.

\footnotetext{
${ }^{11}$ I. Grabska, Jacek Kaczmarski — „Portret zbiorowy we wnętrzu — Dom Opieki”, [w:] I. Grabska, D. Wasilewska, dz. cyt., s. 37.
} 
Specyficzne rozjaśnienie wizji sędziwego wieku w poezji Kaczmarskiego przynosi wiersz Dęby, dedykowany dziadkom artysty, Felicji i Stanisławowi Trojanowskim. Poza wszelkimi zmartwieniami wokół nieprzemijalności sztuki, obecnymi w omówionych utworach pisanych z senilnej perspektywy artystów, czy egzystencjalnymi wątpliwościami, rodzącymi się na przedprożu śmierci — pozostało zwyczajne życie, które nie musi przysparzać jedynie dyskomfortu:

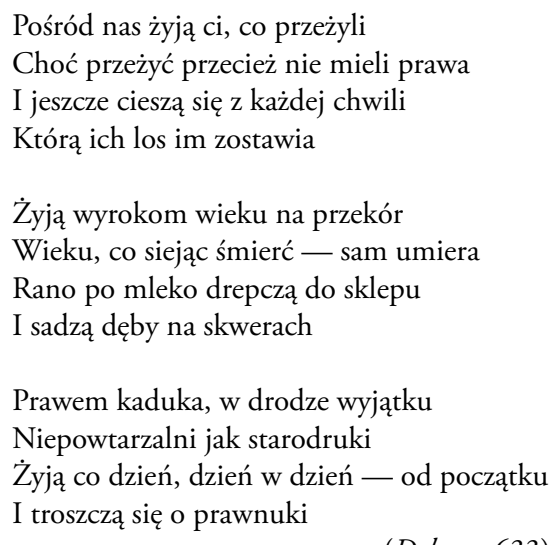

(Dęby, s. 633)

Słusznie zalicza się Dęby do grupy piosenek „poruszających problem roczników, które przeżyły wojnę"12. Zresztą mowa w tym utworze o tych, którzy nie pysznili się faktem ocalenia. Pomimo doznanych i widzianych okrucieństw byli oni pogodzeni ze światem, wyciszeni, wyraziście określeni: „— Jesteśmy częścią kosmosu!”. To inna wizja starości, niż ta, jaką obserwowaliśmy w omówionych dotychczas tekstach. Waloryzuje się tu spokój, mądrość, która pozwala na wzniesienie się ponad hałas codzienności i szum historii, a zarazem nieugięte partycypowanie w świecie poprzez dbałość o budujące go szczegóły. „Popiół we włosach” — metonimia siwizny, opierająca się jednocześnie na przywołaniu kontekstu prochów ludzi spalonych w obozach koncentracyjnych — oprószyła głowy mądrych starców, trwałych tak, jak wieczne dęby, które sami sadzili na skwerach, wznosząc nienapuszone pomniki własnego doświadczenia.

Wypadnie skończyć ten przegląd spojrzeniem na jeden z ostatnich tekstów poety - Starość Tezeusza z tomu Tunel:

W młodości byłem Tezeuszem,

A dzisiaj jestem Minotaurem.

Po mrocznym labiryncie kluczę

Nie mogąc liczyć na Ariadnę.

(Starość Tezeusza, s. 1107)

${ }_{12}$ B. Krupa, Druga wojna światowa w piosenkach Jacka Kaczmarskiego, [w:] Zostały jeszcze pieśni... Jacek Kaczmarski wobec tradycji, red. K. Gajda, M. Traczyk, [Warszawa] 2010, s. 165. 
Po raz kolejny powrócił wątek przechodniości w czasie, dynamicznej przemiany człowieka - w tym wypadku z nieugiętego herosa w napiętnowanego potwora. Mówił Tezeusz-Minotaur: „W młodości byłem bohaterem, / Dziś jestem więźniem ciemnej sławy”, poddając się „pokornemu oczekiwaniu na mordercę”, którym mogą okazać się czas, tłum, sprytniejszy Tezeusz, brutalniejszy Minotaur - to bez różnicy, stary, stający się potworem heros nie liczy na odkupienie. Zaczął widzieć oczami Minotaura, przeistoczył się w swoją ofiarę, utracił własną postać, a razem z nią opuściła go nadzieja, jak Ariadna, na którą nie mógł już liczyć. Widać tu, że ilekroć Kaczmarski dotykał problemu starości, nie chodziło mu jedynie o schyłek życia, ale właśnie o kwestie doświadczenia, poszukiwania sensu w obliczu śmierci, dojrzałości do tego, by przyznać się przed samym sobą do własnych ułomności. Zarazem jednak sędziwy człowiek to w ujęciu Kaczmarskiego ktoś więcej niż źródło metafory czy bohater liryczny.

Poeta, któremu nie było dane dożyć starości Owidiusza, doświadczył u schyłku swego życia starości Tezeusza. W rekonstrukcji pełnej skali owego przeistoczenia wydatnie pomaga refleksja nad wspomnianymi tutaj tekstami.

Kamil Dźwinel

\section{“I WAS Theseus in My Youth". The PERSPeCtive OF SENILITY IN THE ARTISTIC OUTPUT OF JACEK KaCZMARSKI}

\section{Summary}

The subject of the article is the issue of senility present in the artistic output of Jacek Kaczmarski from its beginning (Old People in the Bus from his debut programme Walls) to its end (The Old Age of Theseus, from the volume The Tunnel, which became an inspiration for taking up this topic). Consequently, I discuss the poems in which the communication perspective can be observed with regard to the subject experiencing the old age (The Old Age of Ovid, the above mentioned The Old Age of Theseus, Old Michelangelo and Pieta Rondanini, The Sleeping Old Poet and other poems), including the texts, in which the old age or an old man are the subjects of reflections (for instance The Old Age of Piotr Wysocki). The chosen topic is supplemented with a consideration of the figure of returning and transformation the innocence to experience - this is where the actual and indispensable comparison of the old age and youth is going to participate.

Słowa kluczowe: bard, Jacek Kaczmarski, piosenka literacka, przemiany motywu literackiego, starość artysty

Keywords: bard, Jacek Kaczmarski, literary song, transformations of a literary motif, senility of artist 